\title{
OPEN
}

Published online: 19 March 2020

\section{Author Correction: Cerebral glucose metabolism and Cerebral blood flow in thyroid dysfunction: An Activation Likelihood Estimation Meta-analysis}

\author{
Kyoungjune Pak $\mathbb{D}$, Mijin Kim, Keunyoung Kim, Bo Hyun Kim, Seong-Jang Kim \& In Joo Kim \\ Correction to: Scientific Reports https://doi.org/10.1038/s41598-020-58255-5, published online 28 January 2020 \\ In the original PDF version of this Article, Seong Jang Kim and In Joo Kim were incorrectly listed as correspond- \\ ing authors.
}

Additionally, Mijin Kim was omitted as a corresponding author. Correspondence and request for materials should be addressed to ilikechopin@me.com and mijinkim08@gmail.com. These errors have now been corrected in the HTML and PDF versions of the Article.

(c) (i) Open Access This article is licensed under a Creative Commons Attribution 4.0 International cc) License, which permits use, sharing, adaptation, distribution and reproduction in any medium or format, as long as you give appropriate credit to the original author(s) and the source, provide a link to the Creative Commons license, and indicate if changes were made. The images or other third party material in this article are included in the article's Creative Commons license, unless indicated otherwise in a credit line to the material. If material is not included in the article's Creative Commons license and your intended use is not permitted by statutory regulation or exceeds the permitted use, you will need to obtain permission directly from the copyright holder. To view a copy of this license, visit http://creativecommons.org/licenses/by/4.0/.

(c) The Author(s) 2020 